\title{
CORRIGENDUM
}

\section{Incremental expression of TIr4 correlates with mouse resistance to Salmonella infection and fine regulation of relevant immune genes}

M-F Roy, L Larivière, R Wilkinson, M Tam, MM Stevenson and D Malo

Genes and Immunity (2006) 7, 437. doi:10.1038/sj.gene.6364327

Correction to: Genes and Immunity (2006) E-pub ahead of print: June 1, 2006; doi:10.1038/sj.gene.6364309

Since the publication of the above article, the authors have identified an error in the legend inserts of Figure $7 \mathrm{~b}$ and $\mathrm{c}$.
In Figure $7 \mathrm{~b}$, the pale grey vertical bar should be identified as '382 vs 382 Day 4' instead of '382 vs 382 Day $0^{\prime}$. In Figure $7 \mathrm{c}$, the pale grey vertical bar should be identified as ' 382 vs 382 Day 8' instead of '382 vs 382 Day $0^{\prime}$.

The authors would like to apologize for this mistake. 